\title{
SYNTHESIS, CRYSTAL STRUCTURES, AND ANTIBACTERIAL ACTIVITY OF A SERIES OF HYDRAZONE COMPOUNDS DERIVED FROM 4-METHYLBENZOHYDRAZIDE
}

\author{
YAN LEI ${ }^{*}$, TING-ZHEN Li, CHUAN FU, XIAO-LIN GUAN, YAO TAN \\ School of Chemistry \& Environmental Engineering, Chongqing Three Gorges University, Chongqing 404000, P. R. China
}

\section{ABSTRACT}

A series of hydrazone compounds, 4-methyl- $N^{\prime}$-(4-nitrobenzylidene)benzohydrazide methanol solvate (1), $N^{\prime}$-(4-hydroxy-3-nitrobenzylidene)-4methylbenzohydrazide dimethanol solvate (2), and $N^{\prime}$-(3,5-dibromobenzylidene)-4-methylbenzohydrazide (3), derived from 4-methylbenzohydrazide with different benzaldehydes, were synthesized and characterized by physico-chemical methods and single crystal X-ray diffraction. Crystals of the compounds are stabilized by intermolecular hydrogen bonds, as well as $\pi \cdots \pi$ stacking interactions. Antibacterial activity of the compounds against Staphylococcus aureus, Escherichia coli, and Klebsielle pneumoniae strains was studied. Compounds $\mathbf{1}$ and $\mathbf{2}$ have moderate minimum inhibition concentration values on the tested bacteria strains. Compound $\mathbf{3}$, with the Br-substituent groups, showed the highest activity on the bacterial strains.

Keywords: Synthesis; crystal structure; hydrazone compound; hydrogen bonding; antibacterial activity.

\section{INTRODUCTION}

Hydrazides and hydrazones are nowadays of considerable technical and commercial importance due to their wide usage as drugs in medicine and as versatile ligands in coordination chemistry. ${ }^{1-4}$ Hydrazones are a special group of compounds in the Schiff base family characterized by the presence of $\mathrm{CH}=\mathrm{N}-\mathrm{N}=\mathrm{C}$. The presence of two inter-linked nitrogens separates them from imines, oximes, etc. Compared to simple hydrazone Schiff bases, acyl, aroyl, and hetero-aroyl Schiff bases have additional donor sites like $\mathrm{C}=\mathrm{O}$, making them more flexible and versatile. This versatility has made hydrazones good polydentate chelating agents that can form a variety of complexes with various transition metals. In recent years, a number of hydrazone compounds have been prepared and investigated for their biological properties such as antibacterial, antifungal, ${ }^{5}$ anticonvulsant, ${ }^{6}$ anti-inflammatory, ${ }^{7}$ antimalarial, ${ }^{8}$ analgesic, ${ }^{9}$ antiplatelets, ${ }^{10}$ antituberculosis, ${ }^{11}$ and anticancer activities. ${ }^{12}$ Hydrazones also act as herbicides, insecticides, nematocides, rodenticides, and plant growth regulators, and are used as plasticizers and stabilizers for polymers, polymerization initiators, antioxidants, etc. ${ }^{13}$ In order to further study on the detailed structures and the antibacterial activity of such compounds, in the present work, a series of new hydrazone compounds, 4-methyl- $N$ '-(4nitrobenzylidene)benzohydrazide methanol solvate (1), $N^{\prime}$-(4-hydroxy-3nitrobenzylidene)-4-methylbenzohydrazide dimethanol solvate (2), and $N$ '(3,5-dibromobenzylidene)-4-methylbenzohydrazide (3) (Scheme 1), derived from 4-methylbenzohydrazide with different aldehydes, were synthesized and structurally characterized.<smiles>COC(=O)c1ccc(/C=N/NC(=O)c2ccc([N+](=O)[O-])cc2)cc1</smiles>

1<smiles>Cc1ccc(C(=O)N/N=C/c2cc(Br)cc(Br)c2)cc1</smiles>

3

Scheme 1. The hydrazone compounds.

\section{EXPERIMENTAL}

Materials and methods: 4-Methylbenzohydrazide, 4-nitrobenzaldehyde, 4-hydroxy-3-nitrobenzaldehyde, and 3,5-dibromobenzaldehyde were obtained from TCI (Shanghai, China). The other chemicals were used as commercially received without further purification. The composition and structures of the compounds were confirmed by means of elemental analysis, ${ }^{1} \mathrm{H}$ NMR, IR spectroscopy and single crystal X-ray diffraction. Elemental analyses $(\mathrm{C}, \mathrm{H}$ and $\mathrm{N}$ ) were performed on Carlo Erba CHNS-O EA 1108 automatic equipment (Chongqing, China). Infrared spectra were recorded using $\mathrm{KBr}$ disks on a Shimadzu 8400S FT-IR spectrophotometer. ${ }^{1} \mathrm{H}$ NMR spectra were performed on a Varian 200 XL instrument.

General method for the synthesis of the compounds: A methanol solution $(20 \mathrm{ml})$ of 4-methylbenzohydrazide $(1.5 \mathrm{~g}, 0.01 \mathrm{~mol})$ was added to a methanol solution $(20 \mathrm{ml})$ of aldehyde $(0.01 \mathrm{~mol})$. The mixture was refluxed for $2 \mathrm{~h}$, and three quarter of the solvent was evaporated to give precipitate, which was filtered off and washed several times with methanol. Single crystals were obtained by recrystallization of the compounds in methanol.

4-Methyl-N'-(4-nitrobenzylidene)benzohydrazide methanol solvate (1): The aldehyde is 4-nitrobenzaldehyde. Yield: $87 \%$. Analysis calculated for $\mathrm{C}_{16} \mathrm{H}_{17} \mathrm{~N} \mathrm{O}$ : C, 60.94; $\mathrm{H}, 5.43 ; \mathrm{N}, 13.33 \%$; found: $\mathrm{C}, 60.81 ; \mathrm{H}, 5.45 ; \mathrm{N}$, $13.39 \% .{ }^{1} \mathrm{H}$ NMR $\left(d^{6}\right.$-DMSO, ppm): $\delta 2.38(\mathrm{~s}, 3 \mathrm{H}), 7.34(\mathrm{~d}, 2 \mathrm{H}), 7.88(\mathrm{~d}, 2 \mathrm{H})$, 8.08-8.35 (m, 4H, C $\left.\mathrm{H}_{3}\right), 8.39(\mathrm{~s}, 1 \mathrm{H}), 11.17(\mathrm{~s}, 1 \mathrm{H}, \mathrm{NH})$. IR data $\left(\mathrm{KBr}, \mathrm{cm}^{-1}\right)$ : $3432\left(\mathrm{br}, \mathrm{w}, v_{\mathrm{OH}}\right), 3216\left(\mathrm{sh}, \mathrm{m}, \mathrm{v}_{\mathrm{NH}}\right), 1656\left(\mathrm{vs}, v_{\mathrm{C}=\mathrm{N}}\right), 1502\left(\mathrm{~s}, \mathrm{v}_{\mathrm{as}} \mathrm{NO}_{2}\right), 1350$ $\left(\mathrm{s}, v_{\mathrm{s}} \mathrm{NO}_{2}\right)$.

N'-(4-Hydroxy-3-nitrobenzylidene)-4-methylbenzohydrazide dimethanol solvate (2): The aldehyde is 4-hydroxy-3-nitrobenzaldehyde. Yield: $95 \%$. Analysis calculated for $\mathrm{C}_{17} \mathrm{H}_{21} \mathrm{~N}_{3} \mathrm{O}: \mathrm{C}, 56.19 ; \mathrm{H}, 5.83 ; \mathrm{N}, 11.56 \%$; found: $\mathrm{C}$, 56.07; H, 5.92; N, 11.67\%. ' ${ }^{2} \mathrm{H}$ NMR ( $d^{6}$-DMSO, ppm): $\delta 2.38(\mathrm{~s}, 3 \mathrm{H}), 7.33(\mathrm{~d}$, $1 \mathrm{H}), 7.41(\mathrm{~d}, 2 \mathrm{H}), 7.88(\mathrm{~d}, 2 \mathrm{H}), 8.15(\mathrm{~d}, 1 \mathrm{H}), 8.36(\mathrm{~s}, 1 \mathrm{H}), 8.45(\mathrm{~s}, 1 \mathrm{H}), 10.95$ $(\mathrm{s}, 1 \mathrm{H}, \mathrm{NH}), 12.23(\mathrm{~s}, 1 \mathrm{H}, \mathrm{OH})$. IR data $\left(\mathrm{KBr}, \mathrm{cm}^{-1}\right): 3435$ (br, w, $\left.v_{\mathrm{OH}}\right), 3213$ (sh, $\left.\mathrm{m}, \mathrm{v}_{\mathrm{NH}}\right), 1651\left(\mathrm{vs}, \mathrm{v}_{\mathrm{C}=\mathrm{N}}\right), 1500\left(\mathrm{~s}, \mathrm{v}_{\mathrm{s}} \mathrm{NO}_{2}\right), 1354\left(\mathrm{~s}, \mathrm{v} \mathrm{NO}_{2}\right)$.

$N^{\prime}$-(3,5-Dibromobenzylidene)-4-methylbenzohydrazide (3): The aldehyde is 3,5-dibromobenzaldehyde. Yield: $89 \%$. Analysis calculated for $\mathrm{C}_{15} \mathrm{H}_{21} \mathrm{Br}_{2} \mathrm{~N}_{2} \mathrm{O}: \mathrm{C}, 45.49 ; \mathrm{H}, 3.05 ; \mathrm{N}, 7.07 \%$; found: $\mathrm{C}, 45.35 ; \mathrm{H}, 3.13 ; \mathrm{N}$, 7.18\%. ' ${ }^{2} \mathrm{H}$ NMR $\left(d^{6}\right.$-DMSO, ppm): $\delta 2.38(\mathrm{~s}, 3 \mathrm{H}), 7.34(\mathrm{~d}, 2 \mathrm{H}), 7.83(\mathrm{~s}, 2 \mathrm{H})$, $7.88(\mathrm{~d}, 2 \mathrm{H}), 7.93(\mathrm{~s}, 1 \mathrm{H}), 8.37(\mathrm{~s}, 1 \mathrm{H}), 12.06(\mathrm{~s}, 1 \mathrm{H}) . \mathrm{IR}$ data $\left(\mathrm{KBr}, \mathrm{cm}^{-1}\right): 3239$ $\left(\mathrm{sh}, \mathrm{w}, \mathrm{v}_{\mathrm{NH}}\right), 1648\left(\mathrm{vs}, \mathrm{v}_{\mathrm{C}=\mathrm{N}}\right)$.

$X$-ray diffraction: Single crystals suitable for X-ray diffraction were selected, glued on fiber glasses and successively mounted on a Bruker APEX II CCD diffractometer equipped with a graphite-monochromatic Mo-Ka radiation $(\lambda=0.71073 \AA)$. The phase problem was solved in both cases by direct methods and the structures were refined by full-matrix least-squares on all measured $F^{2}$ with SHELXL97. ${ }^{14}$ Anisotropic thermal displacement parameters were refined for all non-hydrogen atoms. The amino $\mathrm{H}$ atoms of the compounds were located from difference Fourier maps and refined isotropically, with $\mathrm{N}-\mathrm{H}$ distances restrained to $0.90(1) \AA$. The other hydrogen atoms were located in idealized positions.

Antibacterial test: The compounds were tested for the in vitro 
antibacterial activity against Staphylococcus aureus, Escherichia coli, and Klebsielle pneumoniae strains using the paper disc diffusion method ${ }^{15}$ (for the qualitative determination) and the serial dilutions in liquid broth method $^{16}$ (for determination of MIC (minimum inhibition concentration)). Suspensions in sterile peptone-water from $24 \mathrm{~h}$ cultures of microorganisms were adjusted to $0.5 \mathrm{McF}$ arland standards. Muller-Hinton Petri dishes of $90 \mathrm{~mm}$ were inoculated using these suspensions. Paper disks ( $6 \mathrm{~mm}$ in diameter) containing $10 \mathrm{~mL}$ of the substance to be tested at a concentration of $2048 \mu \mathrm{g} / \mathrm{mL}$ in DMSO were placed in a circular pattern in each inoculated plate. Incubation of the plates was done at $37{ }^{\circ} \mathrm{C}$ for $24 \mathrm{~h}$. Reading of the results was done by measuring the diameters of the inhibition zones generated by the tested substances. Tetracycline was used as a reference. Determination of MIC was done using the serial dilutions in liquid broth method. The materials used were 96-well plates, suspensions of microorganism ( $0.5 \mathrm{McF}$ arland), Muller-Hinton broth (Merck) and stock solutions of each substance to be tested $(2048 \mu \mathrm{g} / \mathrm{mL}$ in DMSO). The following concentrations of the substances to be tested were obtained in the 96-well plates: 1024, 512, 256, 128, 64, 32, 16, 8, 4 and $2 \mu \mathrm{g} /$ $\mathrm{mL}$. After incubation at $37{ }^{\circ} \mathrm{C}$ for $24 \mathrm{~h}$, the MIC for each tested substance was determined by macroscopic observation of microbial growth. It corresponds to the well with the lowest concentration of the tested substance where microbial growth was clearly inhibited.

\section{RESULTS AND DISCUSSION}

Crystal structure description: The molecular structures of $\mathbf{1}, \mathbf{2}$ and $\mathbf{3}$ are shown in Figures 1, 2 and 3, respectively. The crystallographic data for the compounds are summarized in Table 1 . Compound $\mathbf{1}$ contains a hydrazone molecule and a methanol molecule. Compound 2 contains a hydrazone molecule and two methanol molecules. Compound $\mathbf{3}$ contains only a hydrazone molecule, with no solvent molecules. The bond lengths and angles in the compounds are comparable to each other, and within normal ranges. ${ }^{17-21}$ The methanol molecules in $\mathbf{1}$ and $\mathbf{2}$ are linked to the hydrazone molecules through intermolecular $\mathrm{O}-\mathrm{H} \cdots \mathrm{O}, \mathrm{O}-\mathrm{H} \cdots \mathrm{N}$ and $\mathrm{N}-\mathrm{H} \cdots \mathrm{O}$ hydrogen bonds (Table 2 ). In the benzohydrazide molecules, the bond lengths of $\mathrm{C}(9)-\mathrm{N}(2)$ are 1.269(3) $\AA$ for $1,1.275(5) \AA$ for 2 , and $1.264(5) \AA$ for 3 , indicating them as typical double bonds. The distances between atoms C(8) and N(1) [1.362(3) $\AA$ for $\mathbf{1}$, $1.338(5) \AA$ for 2, and 1.353(4) $\AA$ for 3] are intermediate between single and double bonds, due to the conjugation effects of the hydrazone molecules. In the benzohydrazide molecules, the dihedral angles between the $\mathrm{C}(2)-\mathrm{C}(7)$ and $\mathrm{C}(10)-\mathrm{C}(15)$ benzene rings are $4.6(3)^{\circ}$ for $\mathbf{1}, 3.5(5)^{\circ}$ for $\mathbf{2}$, and $12.3(4)^{\circ}$ for $\mathbf{3}$.

In the crystal structure of $\mathbf{1}$, the benzohydrazone molecules are linked by methanol molecules through intermolecular $\mathrm{O}-\mathrm{H} \cdots \mathrm{O}, \mathrm{O}-\mathrm{H} \cdots \mathrm{N}$, and $\mathrm{N}-\mathrm{H} \cdots \mathrm{O}$ hydrogen bonds (Table 2), to form 1D chains running along the $a$ axis (Figure 4 ). In the crystal structure of $\mathbf{2}$, the benzohydrazone molecules are linked by methanol molecules through intermolecular $\mathrm{O}-\mathrm{H} \cdots \mathrm{O}, \mathrm{O}-\mathrm{H} \cdots \mathrm{N}$, and $\mathrm{N}-\mathrm{H} \cdots \mathrm{O}$ hydrogen bonds (Table 2), to form 2D layers parallel to the $a b$ plane (Figure 5). In the crystal structure of $\mathbf{3}$, the benzohydrazone molecules are linked through intermolecular $\mathrm{N}-\mathrm{H} \cdots \mathrm{O}$ hydrogen bonds (Table 2), to form 1D chains running along the $c$ axis (Figure 6). In addition, there are $\pi \cdots \pi$ stacking interactions among the adjacent benzene rings (Table 3 ). ${ }^{22}$

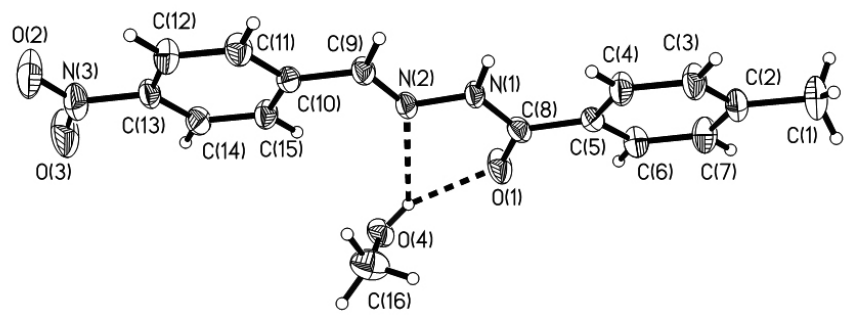

Figure 1 Molecular structure of 1, showing the atom labeling scheme. Displacement ellipsoids are drawn at the $30 \%$ probability level for non- $\mathrm{H}$ atoms. Hydrogen bonds are indicated as dashed lines.

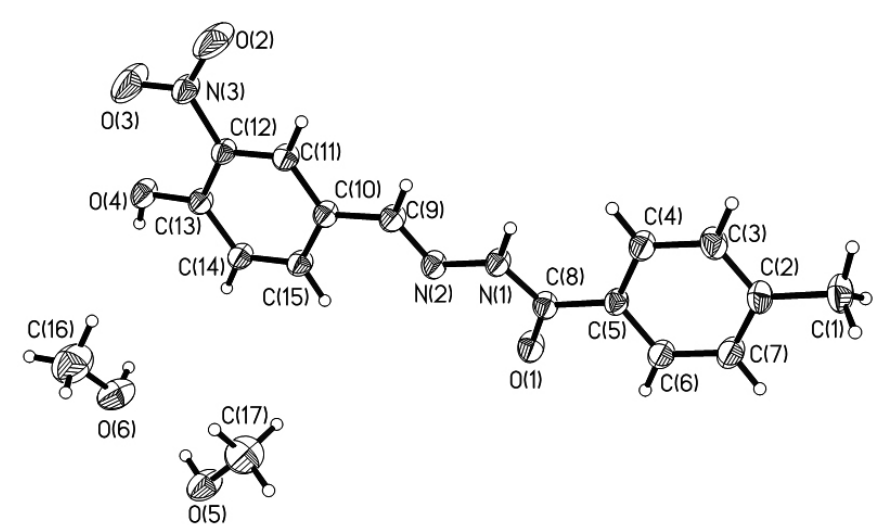

Figure 2 Molecular structure of 2, showing the atom labeling scheme. Displacement ellipsoids are drawn at the $30 \%$ probability level for non- $\mathrm{H}$ atoms.

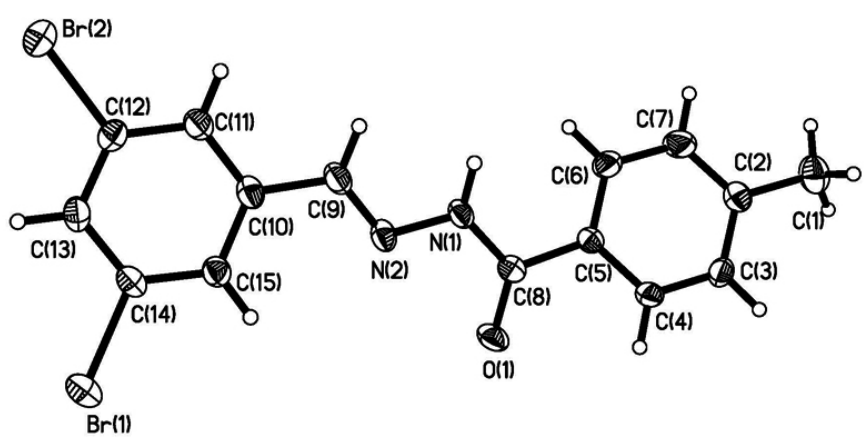

Figure 3 Molecular structure of $\mathbf{3}$, showing the atom labeling scheme. Displacement ellipsoids are drawn at the $30 \%$ probability level for non- $\mathrm{H}$ atoms.

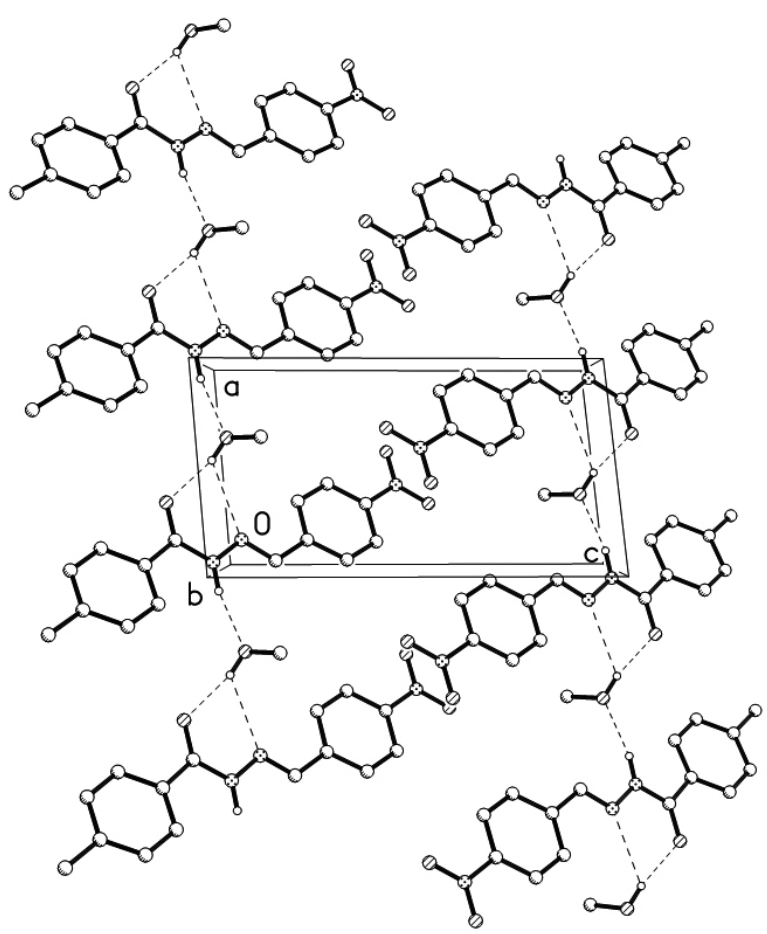

Figure 4 2D hydrogen-bond packing diagram along the $a$ axis for $\mathbf{1}$. Hydrogen bonds are indicated as dashed lines. 
Table 1 Crystallographic data for the compounds.

\begin{tabular}{|c|c|c|c|}
\hline & 1 & 2 & 3 \\
\hline Empirical formula & $\mathrm{C}_{16} \mathrm{H}_{17} \mathrm{~N}_{3} \mathrm{O}_{4}$ & $\mathrm{C}_{17} \mathrm{H}_{21} \mathrm{~N}_{3} \mathrm{O}_{6}$ & $\mathrm{C}_{15} \mathrm{H}_{12} \mathrm{Br}_{2} \mathrm{~N}_{2} \mathrm{O}$ \\
\hline Formula weight & 315.3 & 363.4 & 396.1 \\
\hline Crystal system, space group & Triclinic, $P-1$ & Monoclinic, $P 2_{1} / c$ & Monoclinic, $P 2_{1} / c$ \\
\hline \multicolumn{4}{|l|}{ Unit cell parameters } \\
\hline$a$ & $6.531(1) \AA$ & $9.547(2) \AA$ & $18.574(2) \AA$ \\
\hline$b$ & $10.363(2) \AA$ & $13.642(2) \AA$ & $8.719(1) \AA$ \\
\hline$c$ & $12.165(3) \AA$ & $14.218(2) \AA$ & 9.534(1) $\AA$ \\
\hline$\alpha$ & $93.280(2)^{\circ}$ & $90^{\circ}$ & $90^{\circ}$ \\
\hline$\beta$ & $94.936(2)^{\mathrm{o}}$ & $97.282(2)^{\mathrm{o}}$ & $95.625(2)^{\mathrm{o}}$ \\
\hline$\square$ & $102.089(1)^{\mathrm{o}}$ & $90^{\circ}$ & $90^{\circ}$ \\
\hline Volume & $799.7(3) \AA^{3}$ & $1836.8(5) \AA^{3}$ & $1536.6(3) \AA^{3}$ \\
\hline$Z$, calculated density & 2 & 4 & 4 \\
\hline Absorption coefficient & 0.096 & 0.101 & 5.272 \\
\hline$F(000)$ & 332 & 768 & 776 \\
\hline Crystal size & $0.13 \times 0.12 \times 0.12$ & $0.15 \times 0.13 \times 0.12$ & $0.30 \times 0.27 \times 0.27$ \\
\hline Theta range for data collection & $1.69-27.00$ & $2.15-25.49$ & $2.20-25.50$ \\
\hline Limiting indices & $\begin{aligned}-8 & \leq h \leq 8 \\
-13 & \leq k \leq 13 \\
-15 & \leq l \leq 15\end{aligned}$ & $\begin{aligned}-11 & \leq h \leq 11 \\
-16 & \leq k \leq 16 \\
-17 & \leq l \leq 15\end{aligned}$ & $\begin{aligned}-22 & \leq h \leq 22 \\
-10 & \leq k \leq 10 \\
-11 & \leq l \leq 11\end{aligned}$ \\
\hline Reflections collected/unique & $3345 / 1757\left[R_{\mathrm{int}}=0.0336\right]$ & $3413 / 2086\left[R_{\mathrm{int}}=0.0359\right]$ & $2864 / 2075\left[R_{\mathrm{int}}=0.0535\right]$ \\
\hline Data/restraints/parameters & $3345 / 214 / 1$ & $3413 / 244 / 1$ & $2864 / 185 / 0$ \\
\hline Goodness-of-fit on $F^{2}$ & 1.018 & 1.034 & 1.028 \\
\hline Final $R$ indices $[I>2 \sigma(I)]$ & 0.0656 & 0.0712 & 0.0419 \\
\hline$R$ indices (all data) & 0.1420 & 0.1950 & 0.0853 \\
\hline Largest diff. peak and hole & $0.158,-0.255$ & $0.526,-0.528$ & $0.367,-0.592$ \\
\hline
\end{tabular}

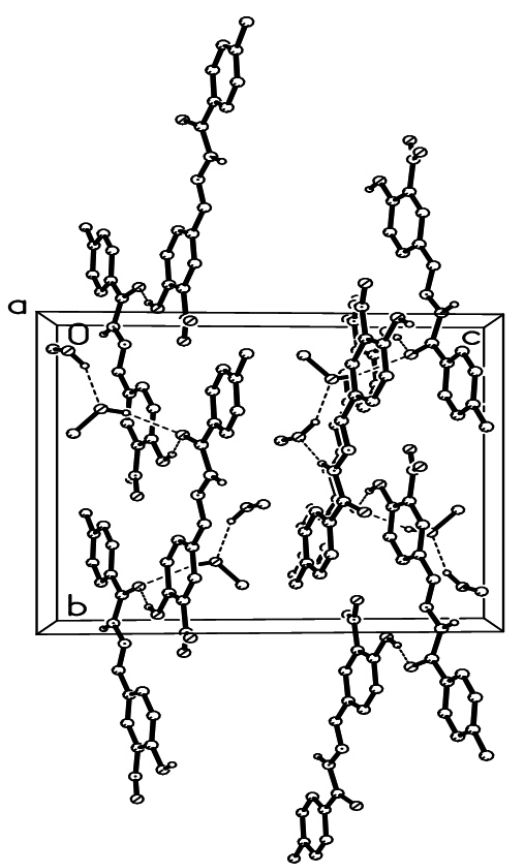

Figure 5 2D hydrogen-bond layers parallel to the $a b$ plane for $\mathbf{2}$. Hydrogen bonds are indicated as dashed lines.

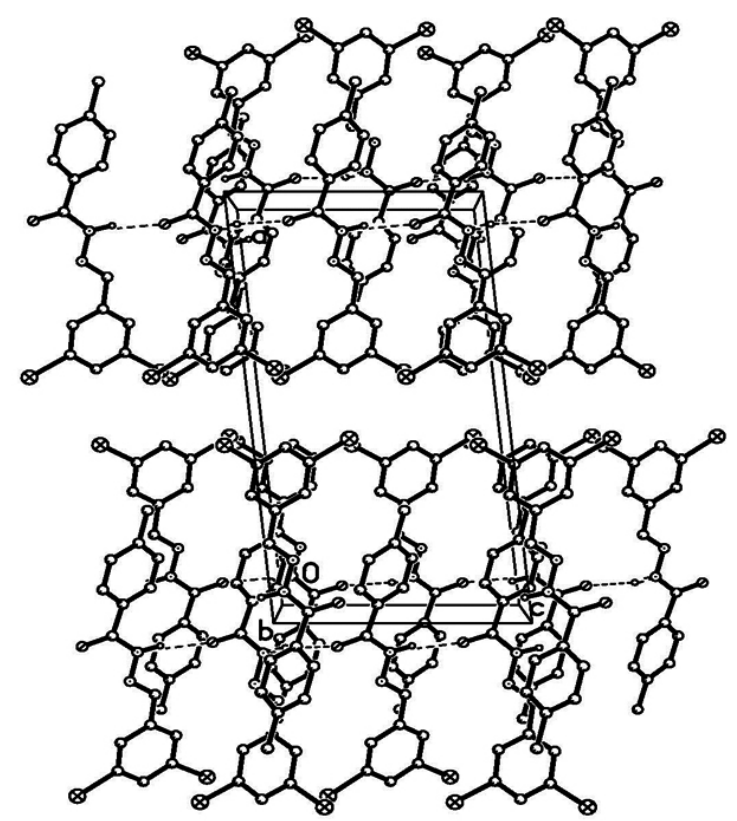

Figure 6 1D hydrogen-bond packing diagram along the $c$ axis for 3 . Hydrogen bonds are indicated as dashed lines. 
Table 2 Distances $(\AA)$ and angles $\left({ }^{\circ}\right)$ involving hydrogen bonds.

\begin{tabular}{|c|c|c|c|c|}
\hline$D-\mathrm{H} \cdots A$ & $d(D-\mathrm{H})(\AA)$ & $d(\mathrm{H} \cdots A)(\AA)$ & $d(D \cdots A)(\AA)$ & Angle $(D-\mathrm{H} \cdots A)\left({ }^{\circ}\right)$ \\
\hline $\mathbf{1}$ & & & & \\
\hline $\mathrm{O}(4)-\mathrm{H}(4) \cdots \mathrm{O}(1)$ & 0.82 & 2.03 & $2.802(2)$ & 157 \\
\hline $\mathrm{O}(4)-\mathrm{H}(4) \cdots \mathrm{N}(2)$ & 0.82 & 2.55 & $3.105(3)$ & 126 \\
\hline $\mathrm{N}(1)-\mathrm{H}(1) \cdots \mathrm{O}(4)^{\mathrm{i}}$ & $0.896(10)$ & $1.967(12)$ & $2.844(2)$ & $165(3)$ \\
\hline $\mathbf{2}$ & & & & 169 \\
\hline $\mathrm{O}(4)-\mathrm{H}(4) \cdots \mathrm{O}(1)^{\mathrm{ii}}$ & 0.82 & 1.89 & $2.698(3)$ & 116 \\
\hline $\mathrm{O}(4)-\mathrm{H}(4) \cdots \mathrm{N}(2)^{\mathrm{ii}}$ & 0.82 & 2.65 & $3.100(4)$ & 156 \\
\hline $\mathrm{O}(5)-\mathrm{H}(5) \cdots \mathrm{O}(6)$ & 0.82 & 1.94 & $2.708(4)$ & 162 \\
\hline $\mathrm{O}(6)-\mathrm{H}(6) \cdots \mathrm{O}(1)^{\mathrm{ii}}$ & 0.82 & 2.00 & $2.794(5)$ & \\
\hline $\mathrm{N}(1)-\mathrm{H}(1) \cdots \mathrm{O}(5)^{\mathrm{iii}}$ & $0.90(1)$ & $2.12(2)$ & $3.005(4)$ & $167(4)$ \\
\hline $\mathbf{3}$ & & & & $2.899(5)$ \\
\hline $\mathrm{N}(1)-\mathrm{H}(1) \cdots \mathrm{O}(1)^{\mathrm{iv}}$ & $0.90(1)$ & $2.02(2)$ & & \\
\hline
\end{tabular}

Symmetry codes: i) $-1+x, y, z$;ii) $1-x, 1 / 2+y, 1 / 2-z$; iii) $-1+x, y, z$; iv) $x, 1 / 2-y,-1 / 2+z$.

Table 3 Parameters between the planes.

\begin{tabular}{|c|c|c|c|c|}
\hline$C_{g}$ & $\begin{array}{c}\text { Distance between } \\
\text { ring centroids }(\AA)\end{array}$ & Dihedral angle $\left(^{\circ}\right)$ & $\begin{array}{c}\text { Perpendicular distance of } \\
C_{g}(\mathrm{I}) \text { on } C_{g}(\mathrm{~J})(\AA)\end{array}$ & $\begin{array}{c}\text { Perpendicular distance of } \\
C_{g}(\mathrm{~J}) \text { on } C_{g}(\mathrm{I})(\AA)\end{array}$ \\
\hline $\mathbf{1}$ & & & & 3.368 \\
\hline$C_{g}(1)-C_{g}(1)^{\mathrm{a}}$ & 5.604 & 0.00 & 3.455 & 3.539 \\
\hline$C_{g}(1)-C_{g}(2)^{\mathrm{b}}$ & 3.782 & 4.61 & 3.794 & 3.794 \\
\hline$C_{g}(2)-C_{g}(2)^{\mathrm{c}}$ & 5.552 & 0.00 & & 3.383 \\
\hline $\mathbf{2}$ & & & 3.483 & 3.589 \\
\hline$C_{g}(1)-C_{g}(2)^{\mathrm{d}}$ & 3.718 & 4.71 & 3.388 & 3.617 \\
\hline$C_{g}(1)-C_{g}(2)^{\mathrm{e}}$ & 4.683 & 3.70 & & \\
\hline $\mathbf{3}$ & & & 3.617 & \\
\hline$C_{g}(1)-C_{g}(1)^{\mathrm{b}}$ & 4.856 & 0.00 & & \\
\hline
\end{tabular}

Symmetry codes: a) $-x, 2-y,-z ; \mathrm{b})-x, 1-y,-z ; \mathrm{c}) 1-x, 1-y, 1-z ; \mathrm{d})-x,-1 / 2+y, 1 / 2-z ; \mathrm{e})-x,-y,-z . C_{g}(1)$ and $C_{g}(2)$ are the centroids of $\mathrm{C}(2)-\mathrm{C}(7)$ and $\mathrm{C}(10)-\mathrm{C}(15)$ of the compounds, respectively.

IR spectra: The broad and weak absorption bands at about $3430 \mathrm{~cm}^{-1}$ are attributed to the methanol and water $\mathrm{O}-\mathrm{H}$ vibrations. The sharp and middle bands at about $3215 \mathrm{~cm}^{-1}$ are assigned to the $\mathrm{N}-\mathrm{H}$ vibrations. The characteristic bands at about $1650 \mathrm{~cm}^{-1}$ are assigned to the vibration of the $-\mathrm{C}=\mathrm{N}-$ stretching vibrations. The presence of $v_{a s}(\mathrm{ONO})$ and $v_{\mathrm{s}}(\mathrm{ONO})$ absorption bands at about 1502 and $1353 \mathrm{~cm}^{-1}$, respectively in the IR spectra of $\mathbf{1}$ and $\mathbf{2}$ suggests the existence of the nitro groups.

Antibacterial activity: The compounds were screened for their antibacterial activities. The results are summarized in Table 4. Compounds $\mathbf{1}$ and $\mathbf{2}$ have moderate minimum inhibition concentration (MIC) values on the tested bacteria strains Staphylococcus aureus, Escherichia coli and Klebsielle pneumoniae. Compound $\mathbf{2}$ is more effective against Staphylococcus aureus than compound 1. Compound $\mathbf{3}$ has the most effective activities against all the three bacterial strains. Structure-activity relationship analysis indicates that the presence of $\mathrm{Br}$-substituent groups in the benzene rings of the compounds may increase the antibacterial activities. The results are in accordance with the literature that the existence of halogen atoms in the compounds can enhance their biological activities. ${ }^{23-25}$ Even though compound $\mathbf{3}$ has the most antibacterial activities among the compounds, it is much less than the control drug Tetracycline. Further work needs to be carried out to explore effective antibacterial materials.
Table 4 Antibacterial activities of the compounds as MIC values (mg/ $\mathrm{mL})$.

\begin{tabular}{|c|c|c|c|}
\hline Compound & $\begin{array}{c}\text { Staphylococcus } \\
\text { aureus }\end{array}$ & $\begin{array}{c}\text { Escherichia } \\
\text { coli }\end{array}$ & $\begin{array}{c}\text { Klebsielle } \\
\text { pneumoniae }\end{array}$ \\
\hline $\mathbf{1}$ & 128 & 512 & 256 \\
\hline $\mathbf{2}$ & 64 & 512 & 256 \\
\hline $\mathbf{3}$ & 4 & 8 & 16 \\
\hline Tetracycline & 0.2 & 1.8 & 1.3 \\
\hline
\end{tabular}

\section{CONCLUSIONS}

A series of hydrazone compounds derived from 4-methylbenzohydrazide with similar nitro- and bromo-substituted benzaldehydes were synthesized and structurally characterized. The physico-chemical analyses confirmed the composition and the structures of the compounds. The antibacterial test shows that the presence of the Br-substituent groups in the compounds induced a visible increase of their action against the bacterial strains. 


\section{ACKNOWLEDGMENTS}

This project was supported by the Scientific and Technological Research Program of Chongqing Municipal Education Commission (Grant No. KJ1401025), the Science and Technology of Wanzhou Science Committee (Grant No. 201403062), and the Youth Foundation of Three Georges University (Grant No. 13QN13)

\section{Supplementary material}

CCDC- 821978 for $\mathbf{1}, 871968$ for $\mathbf{2}$, and 1408394 for $\mathbf{3}$ contain the supplementary crystallographic data for this paper. These data can be obtained free of charge at http://www.ccdc.cam.ac.uk/const/retrieving.html or from the Cambridge Crystallographic Data Centre (CCDC), 12 Union Road, Cambridge CB2 1EZ, UK; fax: +44(0)1223-336033 or e-mail: data_request@ccdc.cam. ac.uk.

\section{REFERENCES}

1. F. Hueso-Urena, A.L. Penas-Chamorro, M.N. Moreno-Carretero, M. Quiros-Olozabal, J.M. Salas-Peregrin, J. Chem. Crystallogr. 29, 283, (1999).

2. A. Ozdemir, G. Turan-Zitouni, Z.A. Kaplancikli, Y. Tunali, J. Enzyme Inhib. Med. Chem. 24, 825, (2009).

3. G. Kucukguzel, A. Kocatepe, E. De Clercq, F. Sahin, M. Gulluce, Eur. J. Med. Chem. 41, 353, (2006).

4. U. Ashiq, R. Ara, M. Mahroof-Tahir, Z.T. Maqsood, K.M. Khan, S.N. Khan, H. Siddiqui, M.I. Choudhary, Chem. Biodivers. 5, 82, (2008).

5. C. Loncle, J.M. Brunel, N. Vidal, M. Dherbomez, Y. Letourneux, Eur. J. Med. Chem. 39, 1067, (2004).

6. Ş.G. Küçükgüzel, A. Mazi, F. Sahin, S. Öztürk, J. Stables, Eur. J. Med. Chem. 38, 1005, (2003).

7. R. Todeschini, A.L.P. de Miranda, K.C.M. da Silva, S.C. Parrini, E.J. Barreiro, Eur. J. Med. Chem. 33, 189, (1998).

8. P. Melnyk, V. Leroux, C. Sergheraert, P. Grellier, Bioorg. Med. Chem. Lett. $16,31,(2006)$
9. P.C. Lima, L.M. Lima, K.C.M. da Silva, P.H.O. Léda, A.L.P. de Miranda, C.A.M. Fraga, E.J. Barreiro, Eur. J. Med. Chem. 35, 187, (2000).

10. C. Cunha, J.M. Figueiredo, J.L.M. Tributino, A.L.P. Miranda, H.C. Castro, R.B. Zingali, C.A.M. Fraga, M.C.B.V. de Souza, V.F. Ferreira, E.J. Barreiro, Bioorg. Med. Chem. 11, 2051, (2003).

11. K.K. Bedia, O. Elçin, U. Seda, K. Fatma, S. Nathaly, R. Sevim, A. Dimoglo, Eur. J. Med. Chem. 41, 1253, (2006).

12. N. Terzioglu, A. Gürsoy, Eur. J. Med. Chem. 38, 781, (2003).

13. A.S. El-Tabl, F.A. Aly, M.M.E. Shakdofa, A.M.E. Shakdofa, J. Coord. Chem. 63, 700, (2010).

14. G.M. Sheldrick, SHELXTL V5.1 Software Reference Manual, Bruker AXS, Inc.: Madison, Wisconsin, USA, (1997).

15. A. Barry, Procedures and theoretical considerations for testing antimicrobial agents in agar media. in: Lorian (Ed.), Antibiotics in Laboratory Medicine, $5^{\text {th }}$ ed. Williams and Wilkins, Baltimore, (1991).

16. Methods for anti-microbial dilution and disk susceptibility testing of infrequently isolated or fastidious bacteria; Approved guideline document M45-A26(19). National committee for clinical laboratory standard, NCCLS, Villanova PA USA, (1999).

17. M. Zhang, D.-M. Xian, H.-H. Li, J.-C. Zhang, Z.-L. You, Aust. J. Chem. $65,343,(2012)$.

18. S.-J. Peng, J. Chem. Crystallogr. 41, 280, (2011)

19. A. Padmaja, A. Begum, P. Ragavaiah, C.S. Devi, Indian J. Chem. B 50, 326, (2011)

20. F.H. Allen, O. Kennard, D.G. Watson, L. Brammer, A.G. Orpen, R. Taylor, J. Chem. Soc. Perkin Trans. 2. S1, (1987).

21. X.-L. Wang, Z.-L. You, C. Wang, J. Chem. Crystallogr. 41, 621, (2011).

22. A.L. Spek, Acta Crystallogr. D65, 148, (2009).

23. L.C. Felton, J.H. Brewer, Science 105, 409, (1947).

24. M. Gopalakrishnan, J. Thanusu, V. Kanagarajan, R. Govindaraju, J. Enzym. Inhib. Med. Chem. 24, 52, (2009).

25. L. Shi, H.-M. Ge, S.-H. Tan, H.-Q. Li, Y.-C. Song, H.-L. Zhu, R.-X. Tan, Eur. J. Med. Chem. 42, 558, (2007). 